\title{
RADIOLOGICAL EVALUATION OF BUILDING MATERIALS USED IN MALUMFASHI, KATSINA STATE, USING GAMMA-RAY SPECTROSCOPY ANALYSIS
}

\author{
${ }^{1}$ Aku, M.O. and ${ }^{2}$ Yusuf, $\mathbf{U}$. \\ ${ }^{1}$ Physics Department, Bayero University, Kano, Kano, State Nigeria \\ ${ }^{2}$ Physics Department, SBRS Funtua, Ahmadu Bello University, \\ Zaria, Kaduna State Nigeria
}

\begin{abstract}
The activity concentrations of naturally occurring radionuclides $\left({ }^{226} R a,{ }^{232} \mathrm{Th}\right.$ and $\left.{ }^{40} \mathrm{~K}\right)$ in building materials (sand, cement, blocks, granite, and paints) used in the construction of buildings in Malumfashi local Government area of Katsina state, Nigeria were determined by means of a gamma-ray spectrometry system using Sodium Iodide thallium activated (NaI(TI)) detector in a low background configuration. The average activity concentrations for ${ }^{226} \mathrm{Ra},{ }^{232} \mathrm{Th}$ and ${ }^{40} \mathrm{~K}$ ranged from 17.07 \pm 4.98 to $50.72 \pm 6.74,23.03 \pm 1.54$ to $42.91 \pm 2.37$ and $84.03 \pm 5.44$ to $363.45 \pm 5.27 \mathrm{Bqkg}^{-}$ 1 respectively. Except for block samples, all the samples mean activity concentrations were less than their respective world averages. The estimated absorbed gamma dose rate (D) ranged from $30.75 \pm 4.22$ to $64.57 \pm 4.78 \mathrm{nGyh}^{-1}$ and the outdoor annual effective dose equivalent (AEDE) varied from $0.038 \pm 0.004$ to $0.06 \pm 0.0051 \mathrm{mSvy}^{-1}$; these values are below the worldwide effective dose of $0.07 \mathrm{mSvy}^{-1}$. The values of radium equivalent activity $\left(R a_{e q}\right)$, the external hazard index $\left(\mathrm{H}_{\mathrm{ex}}\right)$ and the internal hazard index $\left(\mathrm{H}_{\mathrm{in}}\right)$ for all the samples in the present work were lower than the accepted safety limit value of 370 Bqkg $^{-1}$.

Keywords: Radionuclide, hazard indices, gamma-ray spectrometry, building materials, Malumfashi
\end{abstract}

\section{INTRODUCTION}

All building raw materials and products derived from rock and soil contain various amounts of mainly natural radionuclides of the uranium $\left({ }^{238} \mathrm{U}\right)$ and thorium $\left.{ }^{232} \mathrm{Th}\right)$ series, and the radioactive isotope of potassium $\left({ }^{40} \mathrm{~K}\right)$ (El-Taher, 2010). In the ${ }^{238} \mathrm{U}$-series the decay chain segment starting from radium $\left({ }^{226} \mathrm{Ra}\right)$ is radiologically the most important and therefore, reference is often made to ${ }^{226} \mathrm{Ra}$ instead of ${ }^{238} \mathrm{U}$ (AlJundi et al., 2009). These radionuclides are sources of the external and internal radiation exposures in dwellings. The external exposures is usually a result of direct gamma radiation while the inhalation of radioactive inert gases radon ${ }^{222} \mathrm{Rn}$, a daughter product of ${ }^{226} \mathrm{Ra}$ ) and their short lived secondary product lead to the internal exposure of the respiratory tract to alpha particles. The specific activities of ${ }^{226} \mathrm{Ra},{ }^{232} \mathrm{Th}$ and ${ }^{40} \mathrm{~K}$ in building materials and products mainly depend on geological and geographical condition as well as geochemical characteristics of those materials (UNSCEAR, 1993 and El-Taher, 2007).

The radiological impact of the natural radioactivity is due to radiation exposure of the body by gamma-rays and irradiation of lung tissues from inhalation of radon and its progeny. From the natural risk point of view, it is necessary to know the dose limit of public exposure and to measure the natural radiation level in the environment caused by ground, air, water, food, building interiors, etc.(El-Taher and Makhluf, 2010). Low level gamma-ray spectrometry is suitable for both qualitative and quantitative determination of gamma- ray emitting nuclides in the environment. The concentration of radioactive element in building materials and its components are important in assessing population exposures, as most individuals spend $80 \%$ of their time indoors. The average indoor absorbed dose rate in air from terrestrial sources of radioactivity is estimated to be $70 \mathrm{nGyh}^{-1}$ (El-Taher, 2012). Great attention has been paid to determining radionuclide's concentration in building materials in many countries (Al-jundi et al., 2009). In building, the highest concentration of radionuclides are found in mineral based materials such as stone, sand, bricks, cement and sediment (Jonathan et al., 2013). The present work therefore is devoted to determine the presence of radioactive elements $\left({ }^{226} \mathrm{Ra},{ }^{232} \mathrm{Th}\right.$, and ${ }^{40} \mathrm{~K}$ ) in building materials used in Malumfashi Local Government area, assess the radiological hazards to human health, measure activity concentrations for these natural radionuclides and calculate the radiological parameters (radium equivalent activity $\mathrm{Ra}_{\text {eq, }}$ external hazard index $\mathrm{H}_{\text {ex }}$ internal hazard index $\mathrm{H}_{\text {in, }}$ absorbed dose rate $\mathrm{D}$ and the annual effective dose equivalent AEDE). These radiological parameters will be compared with reported values for other countries in order to determine the hazard effects. The results will be essential for development of data base on the use and management of building materials. Gamma-ray spectroscopy analytical techniques were chosen in this work due to their sensitivity, simplicity and accuracy especially with regard to the analysis of building materials and other environmental samples. 


\section{MATERIALS AND METHODS}

The analysis of this work was carried out at the Centre for Energy Research and Training (CERT), Ahmadu Bello University, Zaria. Sample of granite, sand, blocks, cement and paint were collected in four different locations namely Malumfashi east, Malumfashi south, Malumfashi west, and Malumfashi north, analyzed and all the data obtained (in cps) were converted to the conventional unit of $\mathrm{Bqkg}^{-1}$ using the calibration factors. Energy and efficiency calibration as well as background measurements are part of analytical parameters required for ease of sample analysis and data interpretation in measurements of naturally occurring radioactive materials (NORMs) with gamma spectrometry method

$$
C F_{K}=\frac{c p s\left({ }^{40} K\right)}{B q\left({ }^{40} K\right) / k g}, \quad C F_{R a}=\frac{c p s\left({ }^{226} R a\right)}{B q\left({ }^{226} R a\right) / k g}
$$

A total of twenty one samples were collected and each sample was put into polyethylene bags, tied and labeled appropriately. Double bags were used for each sample to prevent breakage and cross contamination of sample. The samples were air dried for 7 hrs under laboratory temperature (ambient temperature of $27^{\circ} \mathrm{C}$ ) and average relative humidity of $70 \%$ (IAEA, 1989). The samples were then grinded and packed to fill already weighed cylindrical plastic containers of dimension $7.2 \mathrm{~cm}$ in diameter and 6.0 $\mathrm{cm}$ high to satisfy the selected best sample container higher that will adequately match the detector's dimensions, which allowed for the adequate covering of the detector shied (Ibeanu, 1999). Before sealing, the mass of each sample was determined and recorded. The sealing of the sample containers were done in three stages, namely Vaseline wax, candle wax and adhesive masking tape, all done to prevent the escape of ${ }^{222} \mathrm{Rn}$ gas, a daughter product of ${ }^{226} \mathrm{Ra}$.

$$
R a_{e q}=C_{R a}+1.43 C_{T h}+0.077 C_{K}
$$

and were carried out in accordance with the IAEA recommendations (IAEA, 1989).

The assessment of the activity concentration of ${ }^{226} \mathrm{Ra}$, ${ }^{232} \mathrm{Th}$ and ${ }^{40} \mathrm{~K}$ were done using $1764 \mathrm{keV} \mathrm{y}$-line of ${ }^{214} \mathrm{Bi}, 2614 \mathrm{keV} \mathrm{Y}$-line of ${ }^{208} \mathrm{TI}$ and $1460 \mathrm{keV} \mathrm{y}$-line of ${ }^{40} \mathrm{~K}$ respectively. The net peak count rate (cps) for the radionuclide in any sample was obtained by subtracting net peak count rate of the radionuclide from that of the sample. All the obtained cps were converted to conventional units using the calibration factors $\mathrm{CF}_{\mathrm{K}}, \mathrm{CF}_{\mathrm{Ra}}$ and $\mathrm{CF}_{\mathrm{Th}}$ derived by Ibeanu (1999) to determine the activity concentration of radionuclide of interest. The calibration factor values of $6.431 \mathrm{x}$ $10^{-4}, 8.632 \times 10^{-4}$ and $8.768 \times 10^{-4}$ in $\mathrm{cps} / \mathrm{Bqkg}^{-1}$ for $\mathrm{CF}_{\mathrm{K}}, \mathrm{CF}_{\mathrm{Ra}}$ and $\mathrm{CF}_{\mathrm{Th}}$ respectively were obtained using the following:

and $\quad C F_{T h}=\frac{\operatorname{cps}\left({ }^{232} \mathrm{Th}\right)}{B q\left({ }^{232} \mathrm{Th}\right) / \mathrm{kg}}$

The samples were then stored for a minimum period of four weeks to achieve an approximate secular equilibrium between ${ }^{222} \mathrm{Rn}$ and ${ }^{232} \mathrm{Th}$, and their respective progeny before commencement of measurement. The samples were then counted for $29,000 \mathrm{sec}$ in a low-level gamma counting spectrometer comprising a $7.6 \mathrm{~cm}$ x $7.6 \mathrm{~cm} \mathrm{NaI}(\mathrm{TI})$ detector which is coupled to multichannel analyzer (MCA) through a preamplifier base. The spectral and live times of the NORMs were acquired using MAESTRO software.

Radium equivalent activity $\left(\mathrm{Ra}_{\mathrm{eq}}\right)$ is an index that has been introduced to represent the specific activities of ${ }^{226} \mathrm{Ra},{ }^{232} \mathrm{Th}$ and ${ }^{40} \mathrm{~K}$ by a single quantity, which takes into account the radiation hazards associated with them. This first index can be calculated according to Nuclear Energy Agency Organization for Economic cooperation and Development (NEA-OECD, 1979) as:

where $C_{R a}, C_{T h}$ and $C_{K}$ are the activity concentrations in building materials samples in $\mathrm{Bqkg}^{-1}$ of ${ }^{226} \mathrm{Ra}$, ${ }^{232} \mathrm{Th}$ and ${ }^{40} \mathrm{~K}$ respectively. The $\mathrm{Ra}_{\mathrm{eq}}$ is related to the external gamma-dose and internal dose due to radon and its daughters.

The gamma outdoor absorbed dose rate (D) at $1 \mathrm{~m}$ above the ground was calculated using the specific activities of ${ }^{40} \mathrm{~K},{ }^{226} \mathrm{Ra}$ and ${ }^{232} \mathrm{Th}$. The conversion factor used to calculate the absorbed dose rates (UNSCEAR, 1993 ) is given as:

$$
D\left(n G y h^{-1}\right)=0.461 C_{R a}+0.623 C_{T h}+0.041 C_{K}
$$

where $C_{R a}, C_{T h}$ and $C_{K}$, are the specific activities of ${ }^{226}{ }^{R a},{ }^{232} \mathrm{Th}$ and ${ }^{40} \mathrm{~K}$ in $\mathrm{Bqkg}^{-1}$ respectively.

The annual effective dose equivalent received outdoor by a member was calculated from the absorbed dose rate by applying dose conversion factor of $0.7 \mathrm{SvGy}^{-1}$ and the occupancy factor for outdoor and indoor was $0.2(5 / 24)$ and $0.8(19 / 24)$ respectively. The effective dose rates in units of $\mathrm{mSvyr}^{-1}$ are calculated by the following formulae (UNSCEAR, 1993)

$$
\begin{aligned}
& A E D E \text { (outdoor) }\left(m S v y^{-1}\right)=D\left(n G y h^{-1}\right) \times 8760 h \times 0.7 S v G y^{-1} \times 0.2 \times 10^{-6} \\
& A E D E \text { (indoor) }\left(m S v y^{-1}\right)=D\left(n G y h^{-1}\right) \times 8760 h \times 0.7\left(S v G y^{-1}\right) \times 0.8 \times 10^{-6}
\end{aligned}
$$


Bajopas Volume 8 Number 2 December, 2015

The external hazard index $\left(\mathrm{H}_{\mathrm{ex}}\right)$ can be defined as (OECD 1979)

$$
H_{e x}=\frac{C_{K}}{4810 B q k g^{-1}}+\frac{C_{R a}}{370 B q k g^{-1}}+\frac{11 C_{T h}}{259 B q k g^{-1}} \leq 1
$$

where $C_{k}, C_{R a}$ and $C_{T h}$ are the specific activities of ${ }^{226} \mathrm{Ra},{ }^{232} \mathrm{Th}$ and ${ }^{40} \mathrm{~K}$ in $\mathrm{Bqkg}^{-1}$ respectively

The internal hazard index $\left(\mathrm{H}_{\text {in }}\right)$ can be defined as (OECD 1979).

$H_{\text {in }}=\frac{C_{K}}{4810 B q g^{-1}}+\frac{C_{R a}}{180 B q k g^{-1}}+\frac{C_{T h}}{259 B q k g^{-1}} \leq 1$

where $C_{R a}, C_{T h}$ and $C_{k}$ are activity concentrations of ${ }^{226} \mathrm{Ra},{ }^{232} \mathrm{Th}$ and ${ }^{40} \mathrm{~K}$, respectively in Bqkg ${ }^{-1}$. These indices must be less than unity in order to keep the radiation hazard insignificant for the people living in the investigated area

(UNSCEAR,

1993).

\section{RESULTS AND DISCUSSION}

The average measured radioactivity concentrations of $\left({ }^{226} \mathrm{Ra},{ }^{232} \mathrm{Th},{ }^{40} \mathrm{~K}\right)$ are presented in Table1. The mean activity concentrations of ${ }^{226} \mathrm{Ra}$ in sand, granite, cement, paint are lower than that of the world mean and that of block sample is slightly higher than that of the world mean for soil, $35 \mathrm{Bqkg}^{-1}$. Also the average concentration of ${ }^{232} \mathrm{Th}$ in block sample is slightly higher than that of the world mean for soil 30 $\mathrm{Bqkg}^{-1}$ (UNSCEAR, 2000). While the activity levels of all the samples are within the world wide range.

Table 1: Average mean activity concentrations of ${ }^{226} \mathrm{Ra},{ }^{232} \mathrm{Th}$ and ${ }^{40} \mathrm{~K}$ for building materials used in study area and that of World Mean.

\begin{tabular}{llccc}
\hline S/NO & MATERIALS & $\begin{array}{c}\mathrm{C}_{\mathrm{K}} \\
\left(\mathrm{Bqkg}^{-1}\right)\end{array}$ & $\begin{array}{c}\mathrm{C}_{\mathrm{Ra}} \\
\left(\mathrm{Bqkg}^{-1}\right)\end{array}$ & $\begin{array}{c}\mathrm{C}_{\mathrm{Th}} \\
\left(\mathrm{Bqkg}^{-1}\right)\end{array}$ \\
\hline 1 & Cement & $210.00 \pm 4.19$ & $30.25 \pm 2.47$ & $29.68 \pm 2.97$ \\
2 & Sand & $282.19 \pm 6.13$ & $17.39 \pm 3.47$ & $36.89 \pm 2.09$ \\
3 & Granite & $235.70 \pm 2.48$ & $19.41 \pm 2.84$ & $23.03 \pm 1.54$ \\
4 & Paint & $84.03 \pm 5.44$ & $17.07 \pm 4.98$ & $25.82 \pm 1.52$ \\
5 & Blocks & $363.45 \pm 5.27$ & $50.72 \pm 6.74$ & $42.91 \pm 2.37$ \\
6 & World Mean & 400 & 35 & 30 \\
7 & World Range & $140-850$ & $17-60$ & $11-64$ \\
\hline
\end{tabular}

The average values of radium equivalent activity $\left(R a_{e q}\right)$, absorbed dose rate (D), external hazard indices $\left(\mathrm{H}_{\mathrm{ex}}\right)$, internal hazard indices $\left(\mathrm{H}_{\mathrm{in}}\right)$ and annual effective dose equivalent (AEDE) are presented in Table 2

Table 2: Mean $\left(\mathrm{Ra}_{\mathrm{eq}}\right),(\mathrm{D}),\left(\mathrm{H}_{\mathrm{ex}}\right),\left(\mathrm{H}_{\mathrm{in}}\right)$ and $(\mathrm{AEDE})$ for the building materials in Malumfashi

\begin{tabular}{lllllll}
\hline $\mathrm{S} / \mathrm{N}$ & Materials & $\mathrm{Ra}_{\mathrm{eq}}\left(\mathrm{Bqkg}^{-1}\right)$ & $\mathrm{D}\left(\mathrm{nGyh}^{-1}\right)$ & $\mathrm{H}_{\mathrm{ex}}$ & $\mathrm{H}_{\mathrm{in}}$ & AEDE $\left.(\mathrm{mSvy})^{-1}\right)$ \\
\hline 1 & Cement & $79.77 \pm 5.33$ & $36.51 \pm 3.07$ & $0.24 \pm 0.02$ & $0.33 \pm 0.01$ & $0.037 \pm 0.003$ \\
2 & Sand & $96.01 \pm 7.13$ & $38.80 \pm 3.23$ & $0.25 \pm 0.03$ & $0.28 \pm 0.02$ & $0.043 \pm 0.004$ \\
3 & Blocks & $143.87 \pm 13.50$ & $64.51 \pm 4.78$ & $0.33 \pm 0.02$ & $0.52 \pm 0.05$ & $0.06 \pm 0.005$ \\
4 & Granite & $72.64 \pm 5.23$ & $32.56 \pm 3.75$ & $0.17 \pm 0.01$ & $0.25 \pm 0.03$ & $0.056 \pm 0.003$ \\
5 & Paint & $60.61 \pm 4.50$ & $30.75 \pm 4.21$ & $0.16 \pm 0.02$ & $0.21 \pm 0.04$ & $0.038 \pm 0.004$ \\
6 & world mean & $<370$ & 55 & $<1$ & $<1$ & 0.07 \\
\hline
\end{tabular}

The $\mathrm{Ra}_{\mathrm{eq}}$ values for the building materials were found to be within the range of $60.61 \pm 4.5$ to $143.87 \pm 13.50$ $\mathrm{Bqkg}^{-1}$ and are less than $370 \mathrm{Bqkg}^{-1}$, which are acceptable for safe use (OECD, 1979). Also the average values of absorbed dose rates (D) are in the range $30.75 \pm 4.22$ to $64.51 \pm 4.78$ and found to be comparable to the world average of $55 \mathrm{nGyh}^{-1}$ (OECD, 1979). The Annual effective dose equivalent (AEDE) for the different building materials samples in this study varied from $0.037 \pm 0.003$ to $0.06 \pm 0.005$
$\mathrm{mSvy}^{-1}$ are below the permissible limit and are comparable with the worldwide effective dose of 0.07 $\mathrm{mSvy}^{-1}$ (UNSCEAR, 2000). The calculated values of external hazard index obtained were in the range of $0.16 \pm 0.02$ to $0.33 \pm 0.01$ and the internal hazard index values ranges from $0.21 \pm 0.04$ to $0.52 \pm 0.05$. The area is underlain by crystalline rocks of the Basement Complex, which greatly influences the relief. The observed variations in concentrations of the radionuclides may be a reflection of the differences in the geochemistry of the samples and 
Bajopas Volume 8 Number 2 December, 2015

other climatic conditions. The area of study falls within the Tropical Continental Climatic Zone; with a cool dry (harmattan) season from December to February; a hot dry season from March to May; a warm wet season from June to September; a less marked season after rains during

the months of October to November, characterised by decreasing rainfall and a gradual lowering of temperature.

\section{CONCLUSION}

The values of calculated radiation parameters such as dose rate, annual effective dose equivalent, radium equivalent, external hazard index and internal hazard

\section{REFERENCES}

Al-Jundi J., Ulanovskly A. and Pro hl G. (2009): "Doses of External Exposure in Jordan Houses due to Gamma- Emitting Natural Radionuclide in Building Materials", Journal of Environmental Radioactivity 100, pp 841-846

El-Taher A. (2007): "Determination of Rare Earth Elements in Egyptian Granite By Instrumental Neutron Activation Analysis", Journal of Applied Radiation and Isotopes 65, 458-464.

El-Taher A,(2010): "Gamma spectroscopic analysis and associated radiation hazards of building materials used in Egypt", Radia. Prot. Dosi. 138 (2): 158-165.

El-Taher, A. (2012): "Assessment of natural radioactivity levels and radiation hazards for building materials used in Qassim area, Saudi Arabia". Romanian journal of physics. vol. 57,Nos.3-4, p.726-735, Bucharest,.

El-Teher A. and Makhluf S. (2010): "Natural Radioactivity Levels in Phosphate Fertilizer and its Environmental Implication in Assuit Governorate , Upper Egypt", Indian. Journal of Pure and Applied Physics 48, pp 697-702.

IAEA, International Atomic Energy Agency (1989): "Measurement of Radionuclide's in Food and Environment", Technical Report Series, No.29.

Muazu, I. (2001): "Radioactivity Measurement in Soil and Rocks from Phosphate and Gypsum Mines in sokoto state, Nigeria", MSc. Thesis, Ahmadu Bello University, Zaria. index are lower than the permissible limit. On the basis of this, none of the samples considered pose any significant radiation hazard and their usage by inhabitants for different kinds of dwellings is considered safe.

\section{RECOMMENDATION}

There could be health risks originating from other source(s) and therefore there will be need to carry out similar researches in order to establish a comprehensive and reliable reference data for the building materials, water, soil and other related environmental materials. It is also important to check the risks associated with level of radioactive elements and heavy or toxic elements.

Ibeanu, I. G. E. (1999): "Assesment of Radiological Effects of Tin Mining Activities in Jos and its Environments", Ph.D Thesis, Ahmadu Bello University, Zaria, Nigeria.

Jonathan O. A., Paul J., and Bashiru B.,B.(2013): "Assessment of Radiological Hazard Indices of Building Materials in Ogbomoso, SouthWest Nigeria", Journal of Environmental Resources Vol(3) NO 2, pp128-131.

NEA- OECD, Nuclear Energy Agency, Organization for Economic Cooperation and Development (1979): "Exposure to Radiation from the Natural Radioactivity in Building Materials", Report by a Group of Experts of OECD Nuclear Energy Agency. Paris, France

UNSCEAR, United Nations Scientific Committee on Effects of Atomic Radiation (1993): "Sources and effects of ionizing radiation", Report to General assembly, with scientific annexes United Nation, New York.

UNSCEAR, United Nations Scientific Committee on Effects of Atomic Radiation (2000): "Sources, effects and risks of ionizing radiation". United Nations, New York. 